\title{
EVALUATION OF EXTERNALITIES IN THE LONG-TIME INFLUENCED MINING AREA IN ORLOVÁ - PORUBA OCEŇOVÁNÍ EXTERNALIT V ÚZEMÍ DLOUHODOBĚ OVLIVNĚNÉM DOBÝVÁNÍM UHLÍ V LOKALITĚ ORLOVÁ - PORUBA
}

\author{
Jana POLANSKÁ ${ }^{1}$, Eva LACKOVÁ ${ }^{2}$, Barbara STALMACHOVÁ ${ }^{3}$ \\ ${ }^{1}$ Mgr., Institute of Environmental Engineering, Faculty of Mining and Geology, VŠB-Technical \\ University of Ostrava, 17.listopadu 15, Ostrava, tel. (+420) 605271250 \\ e-mail:jana.czl@post.cz \\ ${ }^{2}$ Ing., Institute of Environmental Engineering, Faculty of Mining and Geology, VŠB-Technical \\ University of Ostrava, 17.listopadu 15, Ostrava, tel. (+420) 777624992 \\ e-mail: eva.lackova.st@vsb.cz \\ ${ }^{3}$ doc., Ing .,CSc., Institute of Environmental Engineering, Faculty of Mining and Geology, V̌̌B- \\ Technical University of Ostrava, 17.listopadu 15, Ostrava, tel. (+420) 597323544 \\ e-mail: barbara.stalmachova@vsb.cz
}

\begin{abstract}
The article analyses the basic issues of procedural methods for evaluating the environment affected by the exploitation of mineral resources. The paper deals with the area, which was affected by black coal extraction already in the last century and is located in the area of Orlová-Poruba. Tthe first part explicates the basic concepts of landscape restoration issues, views of the methods of assessment and evaluation of the environment and related negative and positive externalities incurred. Another part of this paper assesses the affected area using the so-called Hessian method. Finally, we assess possible solutions of the evaluation of mostly positive externalities ocurred under the conditions in the Czech Republic and the desirability of the proposed new methodology for environmental assessment, including possible solutions.
\end{abstract}

\begin{abstract}
Abstrakt
Článek rozebírá základní problematiku metod postupů oceňování životního prostředí postiženého těžbou nerostných surovin. Př́spěvek se zabývá územím, které bylo postiženo dobýváním černého uhlí již v minulém století a nachází se v lokalitě Orlová-Poruba. Tato problematika je řešena v rámci projektu Grantové agentury GA 105/08/1072. V první části rozebíráme základní pojmy problematiky obnovy krajiny, pohledy na metody hodnocení a oceňování životního prostředí a stímto souvisejícími vzniklými negativními a pozitivními externalitami. Další část tohoto př́spěvku hodnotí postižené území s využitím tzv. Hessenské metody. V závěru hodnotíme možnosti řešení ocenění převážně vzniklých pozitivních externalit $\mathrm{v}$ podmínkách ČR a vhodností nově navrhované metodiky hodnocení životního prostředí, včetně možných východisek.
\end{abstract}

Key words: environmental evaluation, real functional potential, positive externalities

\section{INTRODUCTION}

The mining industry in the world provides natural resources for consumption, offers jobs, provides people with earnings and, last but not least, state tax revenues. From this perspective, it is a very important industrial sector with a positive outcome for society. However, mining activities also bring with harmful side effects, called external effects or externalities. The mining industry is deeply concerned in recent years about the externalities arising in connection with the environment. We talk about the existence of externalities, if an activity of an entity causes a change of welfare to another entity without this change was compensated. An external effect may also be, to some extent, an unintended side effect of an activity and as a cost or benefit of a market transaction it is not included in the price of products or services exchanged. From an environmental perspective, the focus of interest are negative externalities such as contamination of water, soil, air and biodiversity loss (Šimíčková, 1998). However, there are also positive externalities that may outweigh the 
negative ones. The Public Administration and the Czech Mining Authority shall convince and inform society about the positive externalities resulting from exploitation. These include e.g. the reduction of unemployment in the region, a higher level of education due to the construction of schools for workers in mines, promotion of national and international trade and increase in prices of real estates in the given mining region (Romero, 2004).

Coal mining is a time-limited economic activity, that is deemed to be relatively short-term by society. A mining project may somehow contribute to the development of the certain area in a longer term horizon, provided that the closing down of mines and cleaning up the effects of mining activity is precisely given in the plan defined for this purpose. Such plan is a key element for further development of the area and shall include revitalizing actions for the disturbed environment, and consequently the stability of economic and social impacts. Revitalizing actions include the restoration (formation) of the area and landscape disturbed by extraction into stable and productive conditions (Stalmachová, 2006).

Coal mining in the Ostrava-Karviná region has been a very important part of the mining industry in the Czech Republic since the second half of the 19th century. At the Žofie Mine the extraction began in 1874 and was completed in January 1995. During the period of its operation more than 42 million tons of mining output for sale were extracted. The mine field covering an area of 421 hectares is shown in Figure 1 and was opened at a depth of $895 \mathrm{~m}$ by eight pits. The Žofie plant premises under the J. Fucik Mine is located in the southern part of the cadastral territory of Poruba near Orlová (the Municipal District with extended powers to Orlova), in the local part of the Balcar Colony and is part of the Moravian-Silesian Region. The site in question is located in the former mining area of Poruba, which is the smallest mining area in the Karviná part of the Ostrava-Karviná Coalfield (OKR) (Diamo, 2002).

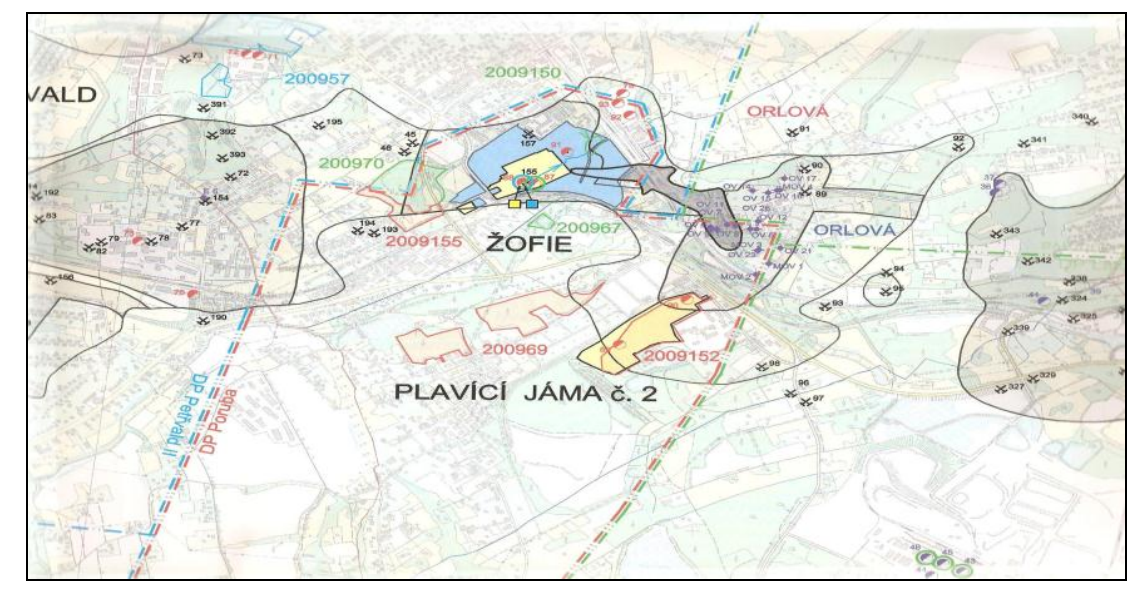

Fig. 1 The Žofie Plant of the J. Fucik Mine (Diamo, 2002)

The project documentation of the Žofie Mine reclamation solved its landscaping including green plantations on the areas that have not been determined for business purposes. Part of the solution was the consolidation of areas that were damaged due to the landfill of various uncontrolled dump-sites and heavy growth of weeds, which acted as allergens and were not aesthetic in this environment. The proposed landscaping and rehabilitation works provided by their nature the utilization of the areas, which have already been rehabilitated by technical adjustments to special-purpose areas for business use. The landscaping involved thinning naturally seeded vegetation, removal of ruderal vegetation, removal of naturally seeded trees from the areas intended for industrial use by the municipal plan (Diamo, 2002).

\section{ENVIRONMENTAL EVALUATION METHODS}

Nature and its resources can be divided into two main groups. One group consists of material resources, occurring on the land surface or below it (soil, water, forests, mineral deposits, territory), which have been for centuries the subject-matter of property and market relationships. Today they are known as natural resources. The second group consists of resources serving as the environment and resources for maintenance of life. These includes the atmosphere, sunlight and all ties and genetic diversity of plant and animal species. These resources remain outside the economic system, are used free of charge and are called environmental resources. The evaluation of any good (thing, service) is usually performed by comparing its supply and demand, or by comparing the costs of the good (supply price) with the expected benefits from its use, or willingness to pay (demand price). However, much more difficult is to valuate goods, for which markets do not exist, as is in the 
case of many natural goods and services. Today science already conclusively knows that nature and its ecosystems are the absolutely necessary and indispensable condition for the existence of life, however, in neoclassical economics (which still prevails in market economies) they have no economic value (Seják, 2003).

To determine the economic value of environmental goods and services the neoclassical environmental economics uses two ways (Turner et al. 1994):

- through the survey of people's willingness to pay for maintaining and improving the quality of the environment, or through the people's willingness to accept compensations for deterioration of these conditions (preferential method),

- through non-preferential approaches, concerning a multi-criteria assessment of costs and risks associated with externalities (expert method). These include methods of recovery costs, opportunity costs, prevention expenses and the method of damage function.

The preferential methods are highly subjective and controllable; specific types of questions asked about particular issues are responded by the laity.

The expert methods generally represent a higher level of objectivity, particularly through the use of a methodological system of positive scientific disciplines. Again, it is true that the result may be influenced by certain subjectivism (e.g. of members of the expert team). However, in principle, it is a method based on the use of available expert knowledge of experts in the field.

The Hessian method as an example of an expert method have been developed in the Land of Hesse in Germany and brought into a specific form of certain fees for the loss (and subsidies for improvement) of ecological functions of the area. Most recently, the Hessian method is also recommended by the European Commission White Paper on environmental liability for the assessment of damage to biodiversity (Seják, 2003). This method for environmental evaluation allows to extend the concept of economic value, as well as the aspect of intrinsic value of the environment, which is enabled by the evaluation not through consumers, but by environmentalists, who have relatively the best knowledge of the intrinsic value of the environment, and so determine the resulting positive and negative externalities. This method takes into account the environmental quality of biotopes, combined with the identified costs of actually performed revitalization, and actually made compensatory measures.

Since we cannot rely on private solutions to externalities, it is necessary to address the impacts of externalities through state interventions. Although it is difficult to suggest the level of state interventions, the government must prevent mainly the emergence of the worst externalities created by the market mechanism. Major state interventions in the area of externalities involve mainly (Šimíčková, 1998): legal restrictions, fines and taxes (environmental taxes), a system of property rights, regulatory rules and regulations (emission, air pollution and concentration limits), subsidies to reduce negative externalities (motivational effect).

In terms of classification the externalities from mining activities can be divided into negative and positive ones. Another option of the division of externalities is the classification into relevant, Pareto relevant, static, dynamic and monetary (pecuniary) externalities (Šimíčková, 1998).

For the calculation especially of the negative externalities, in particular the externalities from the acquisition of land, the methodological procedure set out by the Hessian method is available. The methodology is based on a range of cost values of individual kinds of biotopes, expressed in points per $1 \mathrm{~m}^{2}$ of the area evaluated ranged from 3 to 80 points according to their level of nature (where by 80 points the most valuable biotope is awarded).

The methodology can be described in a simplified way, as follows:

a) make the point assessment of areas of individual biotopes before intervention,

b) make the point assessment of areas after a construction intervention and post-treatment of the areas,

c) calculate the point difference a) - b) and multiply by the specified financial point value,

d) the value obtained represents the quantification of the externalities from the occupation of land (according to the Hessian method known as compensatory fee), the originator of intervention must pay.

To quantify the negative externalities from the operation itself, the method of evaluation according to marginal costs of prevention comes into consideration and/or the method of evaluation of environmental functions of the area using the "Hessian method" (Pěgřímek et al., 2005).

Positive externalities, whether in certain cases, still neglected subconsciously by society, play an irreplaceable role in the process of calculating externalities. Legislative recognition of this term in the subconscious of society is incomplete and the lay public will not be able to imagine the positive effects of the interventions in the environment without the assistance of experts. It is necessary to assemble a team of experts from every sector of human society (e.g., economics, sociology, legislation, etc.) to ensure an objective 
assessment of all the positive effects of this intervention into the environment for the certain locality and society as a whole.

Any positive restoration of functions of living or natural environment may be called a positive external effect, and therefore, while assessing these externalities, we evaluate individual functional components of the landscape. To create a methodical process assessesing the functional potential of the environment, it was needed to look at the various functions of the landscape not in terms of evaluation of "now and here", but "then and here." This expert approach enables the experts evaluating the environment not to forget the view of the future conversion and subsequent created value of the environment over time. This revitalization will strengthen actions to restore the functions of devastated landscape by a tool which will help to choose such revitalizing actions and measures not only the most economical at that moment and best for the landscape, but which, will help due to their future potential to further increase the value of the area.

The evaluation of functional potential results from the values assigned to several sub-criteria of biotic, abiotic and social factors, whose properties interact, complement, or have a common basis. The real function potential, which leads to the calculation of certain external effect is the sum of environmental and social potentials and its overall result is influenced by the coefficient of variation of the use or disturbance of the area. The important part of the evaluation is also a land zoning, which divides the territory affected by underground mining operations into several landscape zones.

The Hessian method is used to express financially the direct conversion of the original value which, however depends on the actual exchange rate, or determination of purchasing power parity, which is specified by EUROSTAT back to year and by the extrapolation for the year ahead and its current status is as follows:

- According to the exchange rate: 1 point $=€ 0.32=\mathrm{CZK} 8.1504$ according to the actual exchange rate of $€ 1$ = CZK 25.47 (May 14, 2010)

- According to the purchasing power parity $(17.6059 \mathrm{CZK} / €-$ average of 2008) 1 point $=€ 0.32=\mathrm{CZK}$ 5.6339

Any differences in the $€$ exchange value may have an impact on the final expression of so-called compensatory fee, which is defined as a financial summary of the different types of externalities (Seják, 2003). Given the fact that the external effect in the case of its financial application burdens the production costs analogously like energy, materials, wages, etc., which enter the domestic production costs in values corresponding to the domestic price level, also for the expression of an external effect its value of purchasing power parity is crucial (Pěgrímek et al., 2005).

The methodology of calculating the real functional potential of the environment will be based on the financial expression of its value by purchasing power parity.

\section{RESULTS AND DISCUSSION}

For the practical application of the "Hessian method" that defines the types of natural biotopes according to the Natura 2000 system under the conditions in the Czech Republic, biotope types have been developed according to (Seják, 2003) listed in the Catalogue of Biotopes in CR, which were assigned a given point value based on the evaluation of eight given characteristics with a possibility to convert this value into a monetary value. The method assesses a certain biotope in terms of the anthropogenic disturbance of potential fullness, and also has to take into account the natural potential of the biotope. However, the method completely ignores the most fundamental property of nature and the given biotopes, namely the property of self-regulation and spontaneous regeneration. Also semi-natural biotopes have these properties, which may due to their evolution over time and self-conversion change the biotope with a low value at this time to the biotope with a much higher point value.

The option of evaluation and assessment of this property of nature characterizes the approach having been processed by us, defined as the real Functional Potential of the area assessed, calculated on the basis of evaluation scales for each factor of biotope/area (Fig. 1).

In compiling the list of biotopes the types of biotopes were grouped into four major groups (Seják, 2003):

- natural and semi-natural biotopes,

- X semi-natural biotopes (X+letter),

- non-natural biotopes (X+digit),

- non-natural biotopes with a limited biota - abiotic ones (XX). 
These biotopes reach the maximum point value - 42 and minimum point value - 0 for abiotic biotopes. When actually evaluating these biotopes, there is a problem at an early stage of rehabilitation, when some of the biotopes are in the early stage of succession, and therefore they are assigned low values, but this assessment is not able also to evaluate the functional potential of this area for a longer time unit. In practice this means that a certain biotope could get a higher point evaluation, if it is evaluated 10 to 30 years after the completion of reclamation and remedial works.

The determination of the real functional potential (of different landscape segments) indicates further practices and options of the use of land and landscape elements, recommends strategies and procedures to protect and restore ecological functions and relationships in different areas and ecosystems, depending on the degree of anthropogenic influence and pressure.

According to the simplified procedure for the methodology of environmental evaluation resulting from the so-called Hessian method, the site of the Žofie Mine in Orlova-Poruba received the values below (Tab.1 and Tab.2):

Tab. 1 Average point value of the area before mining operations before 1861

\begin{tabular}{|c|c|c|c|c|c|}
\hline Number & Type or sub-types of biotopes & Area (\%) & Area $\left(m^{2}\right)$ & $\begin{array}{c}\text { Biotope } \\
\text { value } \\
\left(\mathrm{PV} / \mathrm{m}^{2}\right)\end{array}$ & $\begin{array}{l}\text { Point value of } \\
\text { area (AV) }\end{array}$ \\
\hline 5 & $\begin{array}{l}\text { V1 Macrophyte vegetation of naturally eutrophic and } \\
\text { mesotrophic still waters }\end{array}$ & $0.20 \%$ & $8,428.48$ & 47 & $396,138.75$ \\
\hline 6 & V2.1 Macrophyte vegetation of shallow still waters & $0.40 \%$ & $16,856.97$ & 53 & $893,419.30$ \\
\hline 7 & V2.2 Periodic still waters & $0.01 \%$ & 421.42 & 44 & $18,542.67$ \\
\hline 12 & V4 Macrophyte vegetation of water streams & $2.00 \%$ & $84,284.84$ & 41 & $3,455,678.44$ \\
\hline 17 & M1.1 Reed beds of eutrophic still waters & $0.20 \%$ & $8,428.48$ & 28 & $235,997.55$ \\
\hline 21 & M1.5 Reed vegetation of brooks & $1.24 \%$ & $52,256.60$ & 33 & $1,724,467.83$ \\
\hline 25 & M2.1 Vegetation of exposed fishpond bottoms & $0.03 \%$ & $1,264.27$ & 42 & $53,099.45$ \\
\hline 70 & T1.1 Mesic Arrhenatherum meadows & $5.00 \%$ & $210,712.10$ & 33 & $6,953,499.30$ \\
\hline 72 & T1.3 Cynosurus pastures & $1.00 \%$ & $42,142.42$ & 39 & $1,643,554.38$ \\
\hline 73 & T1.4 Alluvial Alopecurus meadows & $3.00 \%$ & $126,427.26$ & 46 & $5,815,653.96$ \\
\hline 74 & T1.5 Wet Cirsium meadows & $0.50 \%$ & $21,071.21$ & 49 & $1,032,489.29$ \\
\hline 75 & T1.6 Wet Filipendula grasslands & $0.30 \%$ & $12,642.73$ & 46 & $581,565.40$ \\
\hline 89 & T4.2 Mesic herbaceous fringes & $12.00 \%$ & $505,709.04$ & 41 & $20,734,070.64$ \\
\hline 106 & L1 Alder carrs & $6.52 \%$ & $274,768.58$ & 55 & $15,112,271.81$ \\
\hline 108 & L2.2 Ash-alder alluvial forests & $1.43 \%$ & $60,263.66$ & 42 & $2,531,073.75$ \\
\hline 112 & L3.2 Polonian oak-hornbeam forests & $4.20 \%$ & $176,998.16$ & 55 & $9,734,899.02$ \\
\hline 116 & L5.1 Herb-rich beech forests & $0.27 \%$ & $11,378.45$ & 45 & $512,030.40$ \\
\hline 155 & XK1 Extensively managed or fallow vineyards and orchads & $12.00 \%$ & $505,709.04$ & 36 & $18,205,525.44$ \\
\hline 156 & XK2 Fallow land with bushes and trees & $0.20 \%$ & $8,428.48$ & 24 & $202,283.62$ \\
\hline 159 & XL1 Hedgerows and alleys & $3.20 \%$ & $134,855.74$ & 25 & $3,371,393.60$ \\
\hline 160 & XL2 Lone trees & $0.10 \%$ & $4,214.24$ & 25 & $105,356.05$ \\
\hline 174 & X4.4 One-year and autumn plants on arable land & $37.50 \%$ & $1,580,340.75$ & 10 & $15,803,407.50$ \\
\hline \multirow[t]{2}{*}{179} & X5.2 Biotopes of vegetable gardens & $8.70 \%$ & $366,639.05$ & 14 & $5,132,946.76$ \\
\hline & Sum & $100.00 \%$ & $4,214,242.00$ & 873 & $114,249,364.91$ \\
\hline
\end{tabular}


Tab. 2 Average area point value after the reclamation in 2010

\begin{tabular}{|c|c|c|c|c|c|}
\hline Number & Type or sub-types of biotopes & Area $(\%)$ & Area $\left(\mathrm{m}^{2}\right)$ & $\begin{array}{c}\text { Biotope } \\
\text { value } \\
\left(\mathrm{PV} / \mathrm{m}^{2)}\right. \\
\end{array}$ & $\begin{array}{l}\text { Point value of } \\
\text { area (AV) }\end{array}$ \\
\hline 5 & $\begin{array}{l}\text { V1 Macrophyte vegetation of naturally eutrophic and } \\
\text { mesotrophic still waters }\end{array}$ & $0.20 \%$ & $8,428.48$ & 47 & $396,138.75$ \\
\hline 6 & V2.1 Macrophyte vegetation of shallow still waters & $0.50 \%$ & $21,071.21$ & 53 & $1,116,774.13$ \\
\hline 7 & V2.2 Periodic still waters & $0.01 \%$ & 421.42 & 44 & $18,542.67$ \\
\hline 17 & M1.1 Reed beds of eutrophic still waters & $0.20 \%$ & $8,428.48$ & 28 & $235,997.56$ \\
\hline 21 & M1.5 Reed vegetation of brooks & $0.03 \%$ & $1,264.27$ & 33 & $41,721.00$ \\
\hline 25 & M2.1 Vegetation of exposed fishpond bottoms & $0.03 \%$ & $1,264.27$ & 42 & $53,099.45$ \\
\hline 70 & T1.1 Mesic Arrhenatherum meadows & $0.04 \%$ & $1,685.70$ & 33 & $55,628.00$ \\
\hline 73 & T1.4 Alluvial Alopecurus meadows & $0.08 \%$ & $3,371.39$ & 46 & $155,084.11$ \\
\hline 74 & T1.5 Wet Cirsium meadows & $0.02 \%$ & 842.85 & 49 & $41,299.57$ \\
\hline 75 & T1.6 Wet Filipendula grasslands & $0.06 \%$ & $2,528.55$ & 46 & $116,313.08$ \\
\hline 89 & T4.2 Mesic herbaceous fringes & $5.60 \%$ & $235,997.55$ & 41 & $9,675,899.63$ \\
\hline 101 & K1 Willow carrs & $3.00 \%$ & $126,427.26$ & 36 & $4,551,381.36$ \\
\hline 106 & L1 Alder carrs & $2.00 \%$ & $84,284.84$ & 55 & $4,635,666.20$ \\
\hline 108 & L2.2 Ash-alder alluvial forests & $1.00 \%$ & $42,142.42$ & 42 & $1,769,981.64$ \\
\hline 112 & L3.2 Polonian oak-hornbeam forests & $5.20 \%$ & $219,140.58$ & 55 & $12,052,732.12$ \\
\hline 116 & L5.1 Herb-rich beech forests & $0.01 \%$ & 421.42 & 45 & $18,964.09$ \\
\hline 142 & XV4 Locally treated water stress & $2.30 \%$ & $96,927.57$ & 23 & $2,229,334.02$ \\
\hline 143 & XM1 Wet ruderal fallow land & $5.20 \%$ & $219,140.58$ & 19 & $4,163,671.10$ \\
\hline 151 & XT3 Intensively managed and degraded mesic meadows & $2.00 \%$ & $84,284.84$ & 13 & $1,095,702.92$ \\
\hline 155 & $\begin{array}{l}\text { XK1 Extensively managed or fallow vineyards and } \\
\text { orchads }\end{array}$ & $14.20 \%$ & $598,422.36$ & 36 & $21,543,205.10$ \\
\hline 156 & XK2 Fallow land with bushes and trees & $3.10 \%$ & $130,641.50$ & 24 & $3,135,396.05$ \\
\hline 157 & XK3 Trees of railway or road embankments & $2.00 \%$ & $84,284.84$ & 17 & $1,432,842.28$ \\
\hline 159 & XL1 Hedgerows and alleys & $3.60 \%$ & $151,712.71$ & 25 & $3,792,817.80$ \\
\hline 160 & $\mathrm{XL2}$ Lone trees & $0.02 \%$ & 842.85 & 25 & $21,071.21$ \\
\hline 163 & XL5 Glades, forest plants and restoration forest planting & $12.60 \%$ & $530,994.49$ & 17 & $9,026,906.36$ \\
\hline 174 & X4.4 One-year and autumn plants on arable land & $10.00 \%$ & $421,424.20$ & 10 & $4,214,242.00$ \\
\hline 176 & X4.6 Railway stations & $0.90 \%$ & $37,928.18$ & 8 & $303,425.42$ \\
\hline 177 & $\begin{array}{l}\text { X4.7 Wasteland in industrial, deposital and technical- } \\
\text { agricultural areas }\end{array}$ & $2.10 \%$ & $88,499.08$ & 6 & $530,994.49$ \\
\hline \multirow[t]{2}{*}{179} & X5.2 Biotopes of vegetable gardens & $24.00 \%$ & $1,011,418.08$ & 14 & $14,159,853.12$ \\
\hline & Sum & $100.00 \%$ & $4,214,242.00$ & 932 & $100,584,685.20$ \\
\hline
\end{tabular}

The site of the Žofie Mine was affected by mining oprations already in 1861, and therefore for the evaluation of the site environment before a human intervention documents and maps from this period had to be used. These were particularly the maps of the first, second and third military mapping, and also maps from the period of so-called Theresian mapping. (www.google.cz/maps)

The evaluation of the locality after reclamation has been carried out by field survey in the given locality and also using all available map details and other records. The percentage representation of the occurrence of the given biotopes set forth in $\mathrm{m}^{2}$ was multiplied by the point value (PV) for the certain biotope listed in the table of point values of biotopes in the Czech Republic (Seják, 2003), and the resulting value of the area was then used to calculate the monetary expression. If the area before the intervention gets a value higher than the value after performing the reclamation, we talk about the miner's nececiaty to compensate for the loss arised in the form of so-called compensatory fee, which suggests the emergence of a negative external effect. But if the area after reclamation gets a higher point value, we talk about so-called "back pay", which suggests the emergence of a positive external effect. 
For the actual calculation of the evaluation value of the environment it is necessary to subtract the point value of the area after reclamation from the value of the area prior to the commencement of mining operations. The resulting value is multiplied by a specified monetary value of 1 point, which is $€ 0.32$ and represents the quantification of the external effect itself, which the originator must pay to the state (Seják, 2003). For the site of the Žofie Mine in Orlová Poruba the calculation is as follows:

The calculation of the area value according to the exchange rate:

$$
\begin{aligned}
& \mathrm{AV}_{1}=(\mathrm{a}-\mathrm{b}) . € 0.32 \\
& \mathrm{AV}_{1}=€(114,249,364 \cdot 91-100,584,685 \cdot 20) \cdot 0.32 \\
& \mathrm{AV}_{1}=€ 13,664,679.97 \cdot 0.32 \\
& \mathrm{AV}_{1}=13,664,679.97 \cdot 8 \cdot 1504 \\
& \mathrm{AV}_{1}=\mathrm{CZK} 111,372,605 \cdot 40
\end{aligned}
$$

The calculation of the area value by purchasing power parity:

$$
\begin{aligned}
& \mathrm{AV}_{2}=€(\mathrm{a}-\mathrm{b}) \cdot 0.32 \\
& \mathrm{AV}_{2}=€(114,249,364 \cdot 91-100,584,685 \cdot 20) \cdot 0.32 \\
& \mathrm{AV}_{2}=€ 13,664,679.97 \cdot 0.32 \\
& \mathrm{AV}_{2}=13,664,679.97 \cdot 5 \cdot 6339 \\
& \mathrm{AV}_{2}=\mathrm{CZK} 76,985,440.48
\end{aligned}
$$

Where:
$A V_{1}$ - value of area calculated by exchange rate
$\mathrm{AV}_{2}$ - value of area calculated by purchasing power parity
a - point value of site before mining operations
a - point value of site after reclamation

Given that the actual reclamation of the certain area passed all approval mechanisms and was found suitable for the site, the use of this methodology for calculating the monetary value of the area is not appropriate and the question is, whether the newly occurred biotopes, namely the biotopes deemed to be biotopes nature distant, alien and abiotic have properly adjusted characteristics of assigning point values, and whether they are undervalued in the process of environmental assessment by reason that the site is not seen as a cultural landscape that should live in symbiosis with humans, but the site, which was here before arrival of human society.

The following graphs show the percentage proportion of representation of different biotopes in the locality. The number of biotopes nature distant, alien or abiotic increased from 6 to 13 (Graphs 1 and 2). It results also in the amount of the so-called compensatory fee, which would be today unbearable for mining companies, and this type of reclamation would be unfeasible. So a confrontation of views occurs and a need to evaluate the so-called X-biotopes by other suitable methodology, which would take into account the real functional potential of these biotopes and thus raise the current negative external effect into a positive direction.

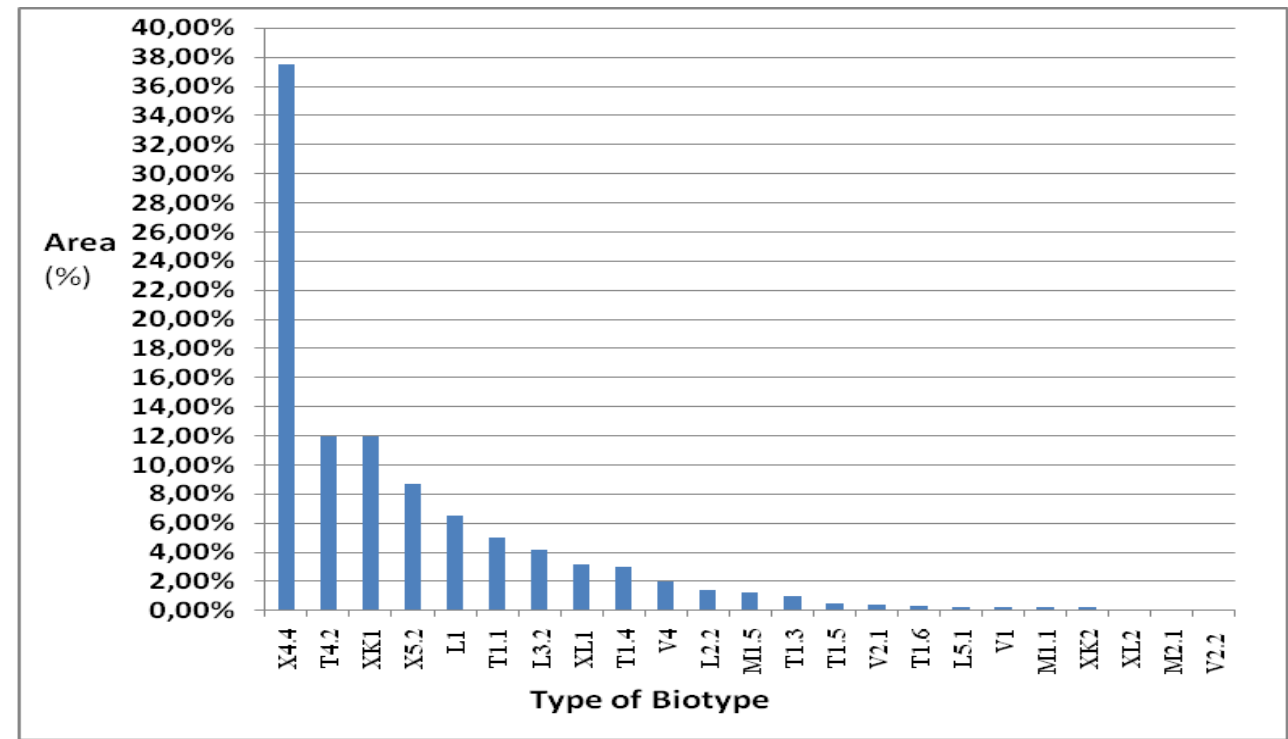

Graph 1: Percentage of different types of biotopes in the Orlová-Poruba locality before extraction 


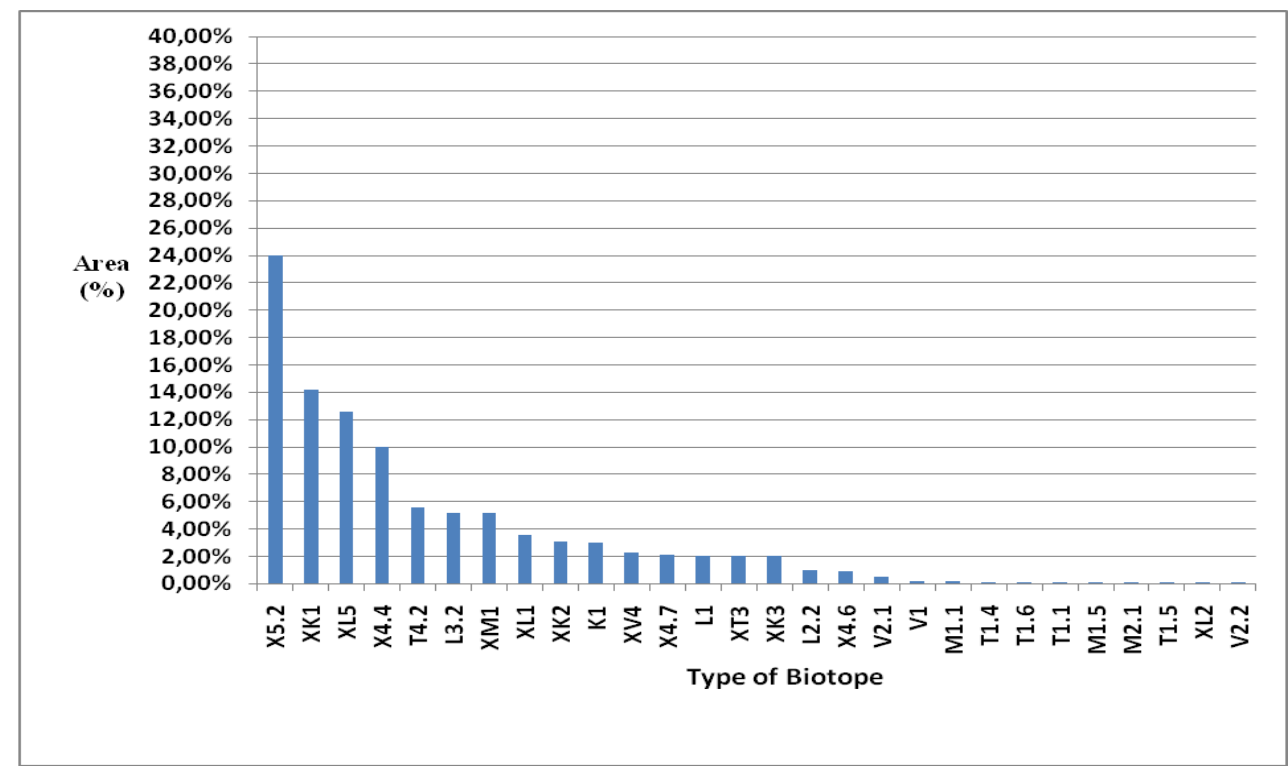

Graph 2: Percentage of different types of biotopes in the Orlová-Poruba locality after reclamation

According to the available materials of reclamation plan indispensable positive effects of the reclamation have been proven on many components of the environment, which we unfortunately were not able to demonstrate in the calculation. Given the above discrepancies in the assessment of so-called negative and positive externalities, we focus on the solution - the establishment of functional potential of different landscape segments that indicate development trends, further practices and possibilities of the use of landscape and landscape elements, recommend strategies and procedures to protect and restore ecological functions and relationships in different areas and ecosystems, depending on the degree of anthropogenic influence and pressure.

The assessment of the functional potential of area will evaluate the following factors and characteristics (Fig. 2):

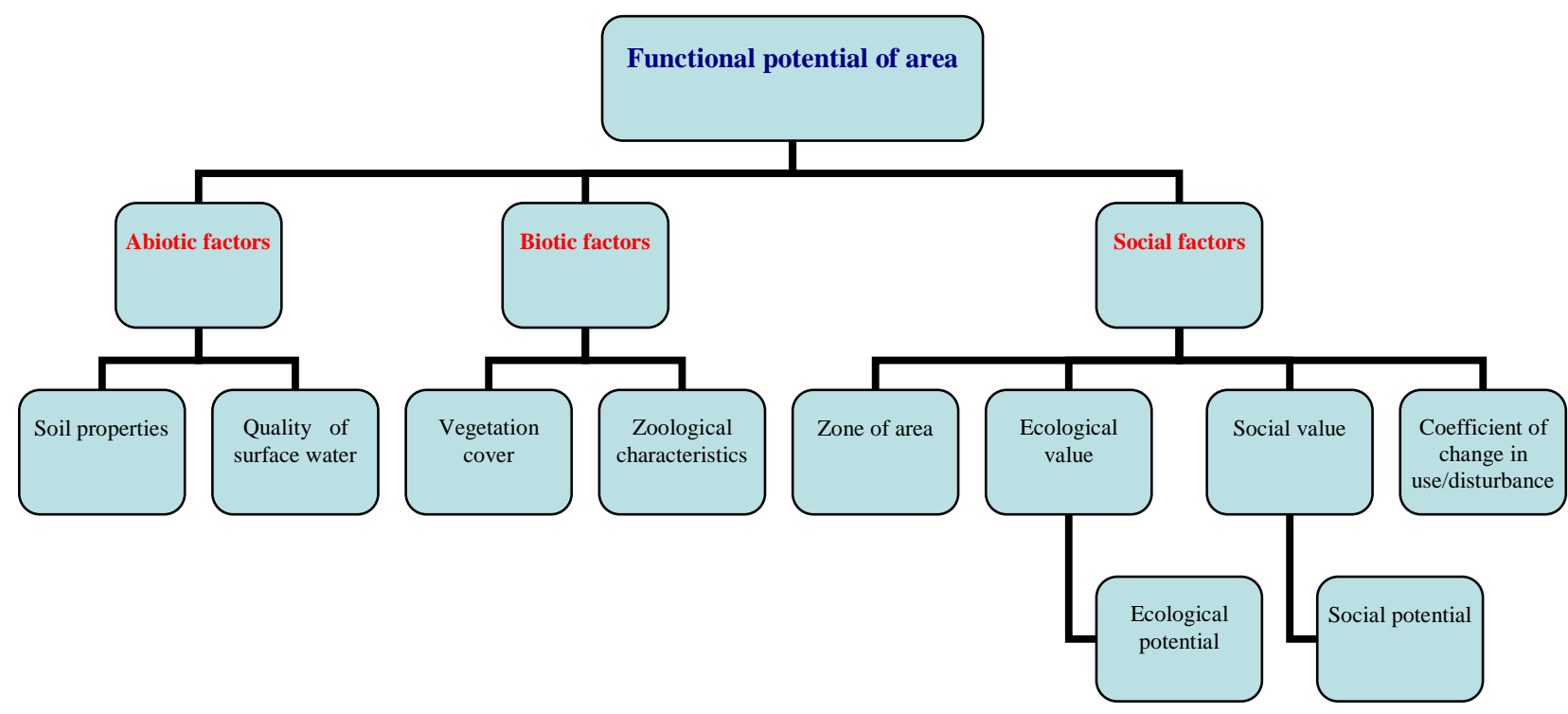

Fig. 2 Evaluation of the area functional potential 


\section{CONCLUSIONS}

The article deals with the assessment of the problems of environmental evaluation of mining landscape, particularly externalities arising from the activities in mining mineral resources. The Hessian method of biotope evaluation was virtually applied to the modelled area of the Žofie Mine and then the monetary value of the environment of the given locality was calculated.

The methodology resulting from the Functional Potential assessment evaluates the area affected by deep mining as an area already influenced by human activities and takes into account the presence of human society, which shapes and finishes the future use of the affected area not only for its own benefit, but also for the benefit of permanently sustainable development.

Various biotopes were evaluated according to the obtained maps and archival sources for the period prior to the commencement of mining, i.e. before 1861 and after the performed treatments of the biotope and biotechnical reclamations, which followed the closures of mining operations on sub-parts of the area. Based on the results achieved, it was found out that the number of biotopes increased from the initial value of 23 to 29 , whereof a substantial part is created by anthropogenic biotopes caused by land reclamations. The total value of the Žofie Mine area was prior to mining operations $114,249,364.89$ points, while after the carried out reclamations it was $100,584,685.21$ points. The difference in these values is $13,664,679.68$ points and indicates the degradation of the territory and reduction of its financial and environmental values. The calculation of the monetary value of the environment by purchasing power parity further indicates the explicit emergence of a clear negative external effect, and perhaps an obligation to pay the compensatory fee in the amount of CZK $76,985,438.85$.

The process according to the Hessian method results in the fact, despite great considerable financial investments into the rehabilitation and improvement of the area condition according to the adopted procedures of reclamation, the area achieves negative results in the evaluation, herewith that the positive effects of reclamation performed are visible already today and we can expect an increasing trend in stability of ecosystems due to the spontaneous recovery or application of the method of controlled succession. These properties are inherent e.g. to semi-natural biotopes, which may due to their evolution over time and self-conversion to change a biotope with a low value at that time to a biotope with a much higher point value. Examples may be young tree stands that are rated very low, but when considering that these forests will create forest units over time, also an increase in their point evaluation with their increasing age can be expected. Furthermore, this approach seems to be questionable as for the performance of point evaluation of each biotope area before intervention, which is only possible for future projects that are planned for the site. This methodological approach eliminates its use also for sites that by their actions already affected the environment in the past. For older locations there are insufficient map materials, data on the diversity of species and diversity of biotope structures, allowing to determine their point value according to the Hessian method, and thus the result of the calculation is modified or distorted.

Given these discrepancies in the assessment of externalities, the project solvers determined the missing points and inconsistencies in the method used. The achieved results indicate in particular the absence of relevant procedures to calculate the point value of biotopes. The current procedures do not consider the increasing point value of newly established biotopes over time, and a variable characterizing the social needs and requirements for the newly established area is missing in the calculation.

In direct response to the missing methodological approaches, showing also positive effects of mining activities, an expert analysis of the issues was initiated at the VSB-Technical University of Ostrava and details for the emergence of new methodological procedure to determine the real functional potential and resulting external effect were prepared. This new methodology will capture the development trends of biotopes, and will count with other practices and options of land use. This suggested expert approach enables the experts, evaluating the environment, not to forget the view of the future conversion and subsequent created value of the environment over time. This will reinforce the prepared actions intended for the restoration of functions of devastated landscape by a tool, which will help to choose such revitalizing actions and measures not only the most economical and best for the landscape at that moment, but also those which due to their future potential will help to increase further the area value.

\section{ACKNOWLEDGEMENTS}

This paper was prepared in connection with the solution of the grant project of GA CR No. 105/08/1072 "Research on quantification of externalities in biotopes typical for cultural landscape in CR and processing a GIS data model". And further the Czech grant project No. SP/201097: Verification and application of methodology for the assessment of externalities of reclaimed and rehabilitated areas of mining landscape. 


\section{REFERENCES}

[1] Concept Note Mine Closure. Mining, Minerals and Sustainable Development Project, London (UK) [online]. [cit. 11/07/2009]. Available from URL <http://www.iied.org/pubs/pdfs/G00950.pdf>

[2] Team of authors of DIAMO, s.p., Odra branch. Rekultivace odvalu Žofie. [Žofie dump reclamation.] GSP s.r.o. Ostrava-Poruba, 2002, No. 60020350, p. 8-17.

[3] PĚGŘÍMEK, R.; PELEŠKA, O.; KRUŽÍK, F. Kvantifikace externalit vznikajicich těžbou a užitím hnědého uhli a algoritmizace výpočtu externalit modifikovanou hessenskou metodou [online]. [Quantification of externalities arising from mining operations and using brown coal and algorithmic calculation of externalities by modified Hessian Method]. [online]. [cit. 2009-7-11].

[4] Available from URL <http://www.czechcoal.cz/cs/ur/spoluziti/CL/4_Peleska_externality_ExternH.pdf>

[5] ROMERO, R. Fostering the Positive Externalities of Mining - Policy Options [online]. [cit. 2009-11-7]. Available from URL <http://www.dundee.ac.uk/cepmlp/journal/html/Vol15/Vol15_16.pdf>

[6] SEJÁK, J.; DEJMAL, I. et al. Hodnocení a ocenování biotopu ČR, [Valuing and Pricing of Biotopes in the Czech Republic], Prague: Český ekologický ústav, Czech Environmental Institute, 2003.

[7] SEJÁK, J., DEJMAL, I. et al. Hodnocení a oceňování biotopů ČR. [Evaluation and pricing of biotopes in CR.] Prague: Český ekologický ústav [Czech Environmental Institute], 2003, p. 450

[8] StAlMACHOVÁ, B. Restoration of the Landscape of Ostravsko and Karvinsko Post-Mining Landscape. Prague: Život. Prostř. [Living Envirinment], 2006, Vol. 40, No. 4, p. 195 - 199.

[9] ŠIMÍČKOVÁ, M. Environmentálni ekonomie I. [Environmental Economy I.] Ostrava: Textbooks of the VSB-TU Ostrava, 1998, p.148, ISBN 80-7078-530-6.

[10] TURNER, K.; PEARCE, D.; BATEMAN, I. Environmental Economics. An Elementary Introduction. Harvester Wheatsheaf, 1994. 